\title{
ANALISIS KEMAMPUAN MENYELESAIKAN SOAL URAIAN DENGAN PEMBELAJARAN PROBLEM POSING TIPE POST SOLUTION DI KELAS VIII SMP NEGERI 1 TALANG EMPAT
}

\author{
Resi Angraini ${ }^{1}$, Agus Susanta $^{2}$, Della Maulidiya ${ }^{3}$ \\ 1,2,3 Program Studi Pendidikan Matematika JPMIPA FKIP Universitas Bengkulu \\ ${ }^{1}$ resiangraini07@gmail.com, ${ }^{2}$ agusunib@yahoo.com, ${ }^{3}$ della.maulidiya@gmail.com
}

\begin{abstract}
Abstrak
Penelitian ini bertujuan untuk mendiskripsikan kemampuan menyelesaikan soal uraian dengan pembelajaran problem posing type post solution. Penelitian ini dilakukan di SMP Negeri 1 Talang Empat. Metode yang digunakan adalah deskriptif kualitatif. Teknik pengumpulan data menggunakan instrumen tes berbentuk soal cerita. Hasil penelitian menyimpulkan bahwa masing-masing kelompok pada tahap penyelesian soal sudah sesuai dengan indikator pencapaian soal.
\end{abstract}

Kata Kunci: kemampuan menyelesaikan soal uraian, pembelajaran problem posing tipe post solution.

\begin{abstract}
This study aims to describe the ability to solve the problem description by learning Problem Posing Post Solution type. This research was conducted in SMP Negeri 1 Talang Empat. The method used was descriptive qualitative. Technique collecting data using test instrument in form of story problem. Based on the results of the study note that each group at the stage of problem solving is in accordance with the indicators of achievement of the problem that has the average score with sufficient and good criteria.
\end{abstract}

Keywords: problem solving, the problem posing learning post solution type.

\section{PENDAHULUAN}

Soedjadi (2000:11) mengemukakan bahwa matematika merupakan ilmu yang selalu diidentikkan dengan segala sesuatu yang bersifat abstrak, perhitungan, penalaran, menghafal rumus, keaktifan berfikir, dan pemahaman-pemahaman teorema yang digunakan sebagai dasar mata pelajaran eksak lainnya. Di sisi lain matematika merupakan bidang studi yang dipelajari siswa dari SD hingga jenjang perguruan tinggi dan matematika juga digunakan sebagai bekal untuk melanjutkan pendidikan ke jenjang yang lebih tinggi. Matematika merupakan salah satu materi pelajaran yang penting dan sangat diperlukan dalam perkembangan ilmu pengetahuan dan teknologi, namun dipihak lain matematika dianggap sebagai mata pelajaran yang menakutkan bagi siswa, sehingga hasil pembelajaran yang diperoleh siswa belum sebagaimana yang diharapkan.

Ngalimun (2012:281) menyimpulkan bahwa problem posing mempunyai tiga pengertian, yaitu: (1)problem posing adalah perumusan soal sederhana atau perumusan ulang soal yang ada dengan beberapa perubahan agar lebih sederhana dan dapat dipahami dalam rangka memecahkan soal yang rumit; (2)problem posing adalah perumusan soal yang berkaitan dengan syarat-syarat pada soal yang telah dipecahkan dalam rangka mencari alternatif pemecahan lain. (3) problem posing adalah merumuskan atau membuat soal dari situasi yang diberikan. Pembelajaran problem posing tipe post-solution adalah memodifikasi kondisi soal yang telah diselesaikan untuk menghasilkan soal baru atau 
membuat soal yang sejenis yang diberikan guru.

Menurut Sudiyono (2008: 118) Tes uraian adalah salah satu jenis tes hasil belajar yang memiliki karakteristik seperti: 1) tes tersebut berbentuk pertanyaan atau perintah yang menghendaki jawaban berupa uraian atau paparan kalimat yang pada umumnya cukup panjang; 2) bentuk-bentuk pertanyaan atau perintah itu menuntut kepada testee untuk memberikan penjelasan, komentar, penafsiran, membandingkan, membedakan dan sebagainya; 3) jumlah butir soalnya umumnya terbatas berkisar antara lima sampai dengan 10 butir.

Rumusan masalah dalam artikel ini adalah bagaimana tingkat kemampuan siswa dalam menyelesaikan soal uraian dengan pembelajaran Problem Posing tipe Post Solution di kelas VIII SMP Negeri 1 Talang Empat tahun ajaran 2016/2017.

Penelitian ini bertujuan untuk mendiskripsikan kemampuan menyelesaikan soal uraian dengan pembelajaran problem posing type post solution.

\section{METODE PENELITIAN}

Jenis penelitian ini adalah penelitian deskriptif kualitatif. Penelitian ini dilaksanakan di SMP Negeri 1 Talang Empat. Subjek dalam penelitian ini adalah siswa kelas VIII B yang terdiri dari 28 siswa. Siswa pada kelas VIII B tersebut diberikan LKS untuk mendeskripsikan kemampuannya dalam menyelesaikan soal uraian. Adapun rubrik penilaian data dalam penyelesaian soal uraian yang terdapat pada LKS, sebagai berikut:

\section{Identifikasi Masalah}

Terdapat tiga indikator dalam identifikasi masalah yaitu menulis lengkap dan benar mendapatkan skor 2, menulis salah mendapat skor 1, dan tidak menulis mendapat skor 0 .

2. Strategi
Terdapat sembilan indikator pada strategi yaitu menulis rumus benar mendapatkan skor 2, menulis rumus yang salah mendapat skor 1, tidak menulis rumus mendapat skor 0 , memiliki perhitungan benar mendapat skor 2 , memiliki perhitungan yang salah mendapat skor 1 , tidak memiliki perhitungan mendapatkan skor 0 , menulis satuan benar mendapatkan skor 2, menuliskan satuan salah mendapat skor 1 , dan tidak menulis satuan mendapatkan skor 0 .

3. Kesimpulan

Terdapat tiga indikator pada kesimpulan yaitu mmenyimpulkan dengan benar mendapatkan skor 2, memberi kesimpulan yang salah mendapat skor 1, dan tidak memberikan kesimpulan mendapatkan skor 0 .

Tabel 1. Penentuan Kriteria

\begin{tabular}{|c|c|}
\hline Interval & Kriteria \\
\hline $0 \leq \mathrm{K}<0,67$ & Kurang \\
\hline $0,67 \leq \mathrm{K}$ & Cukup \\
$<1,33$ & \\
\hline $1,33 \leq \mathrm{K}<2$ & Baik \\
\hline
\end{tabular}

\section{HASIL DAN PEMBAHASAN}

Adapun soal uraian yang dikerjakan oleh siswa yang terdapat pada LKS, sebagai berikut: Perhatikan gambar berikut!

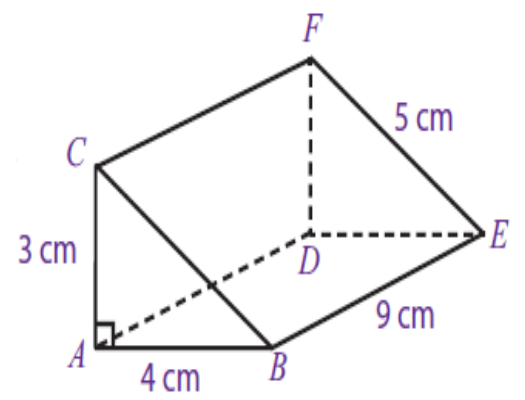

Pada gambar prisma segitiga di atas, tentukan:

a. Luas alas prisma

b. Volume prisma 
Berdasarkan soal uraian diatas diperoleh skor hasil pengerjaan oleh siswa, sebagai berikut:

Tabel 2. Skor Hasil Pengerjaan LKS siswa pada materi volume prisma untuk soal nomor 1

\begin{tabular}{|c|c|c|c|c|c|c|c|c|c|c|}
\hline \multirow{3}{*}{$\begin{array}{c}\text { Kelonpok } \\
\text { Kle. }\end{array}$} & \multicolumn{5}{|c|}{ Sol 1 Bbatangaru } & \multicolumn{5}{|c|}{ Soal 1 Buatan Siswa } \\
\hline & \multirow{2}{*}{ 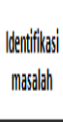 } & \multicolumn{3}{|c|}{ Strotelegi } & \multirow[b]{2}{*}{ Kesimpulan } & \multirow{2}{*}{ 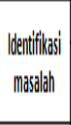 } & \multicolumn{3}{|c|}{ Strotegegi } & \multirow[b]{2}{*}{ Kesimpulan } \\
\hline & & $\begin{array}{l}\text { Menuls } \\
\text { Rumus }\end{array}$ & Pehtitungan & Sotlan & & & \begin{tabular}{|l|} 
Menulis \\
Rumuls \\
\end{tabular} & Penthunganal & Sottan & \\
\hline 1 & 2 & 2 & 2 & 1 & 2 & 2 & 1 & 1 & 1 & 2 \\
\hline 2 & 2 & 2 & 2 & $!$ & 2 & 2 & $!$ & ? & 2 & 2 \\
\hline 3 & 2 & 2 & 2 & $?$ & 2 & 2 & ? & ? & 2 & 2 \\
\hline 4 & 2 & 2 & 2 & 1 & 2 & 2 & 1 & 2 & 2 & 2 \\
\hline 5 & 2 & 2 & 2 & $?$ & 1 & 2 & ? & ! & $?$ & 1 \\
\hline 6 & 2 & 2 & 2 & 1 & 0 & 1 & $!$ & ? & 1 & 0 \\
\hline 7 & 2 & 2 & 2 & 1 & 2 & 2 & $?$ & l & 1 & 2 \\
\hline 8 & 2 & 1 & 1 & 1 & 2 & 2 & 1 & 1 & 1 & 2 \\
\hline 9 & 2 & 2 & 2 & 1 & 2 & 2 & l & l. & 1 & 2 \\
\hline 10 & 2 & 1 & 1 & $!$ & 2 & 2 & 1 & 1 & 2 & 2 \\
\hline 11 & 2 & 1 & 1 & 1 & 2 & 2 & 1 & 1 & 1 & 2 \\
\hline 12 & 2 & 1 & 1 & 1 & 1 & 2 & 1 & 1 & 1 & 1 \\
\hline 13 & 2 & 0 & 1 & 0 & 1 & 2 & 0 & 1 & 0 & 1 \\
\hline 14 & 1 & 0 & 1 & 0 & 0 & 1 & 0 & 1 & 0 & 0 \\
\hline Rotbroth & 1,86 & 1,43 & 157 & 1,29 & 1,5 & 179 & 1,45 & 1.57 & 1,19 & 1,5 \\
\hline Kritreria & baik & 永k & Bajk & culup & Bak & Baik & Bjik & 橰 & coulup & Bdik \\
\hline
\end{tabular}

Berdasarkan tabel 2 di atas terlihat bahwa pada soal buatan guru dan soal buatan siswa terdapat 4 kelompok yang tahap penyelesaian soal sudah sesuai dengan indikator. Selanjutnya, ada 6 kelompok pada soal buatan guru dan soal buatan siswa tidak mengidentifikasi masalah dengan benar, menulis rumus yang salah, memiliki perhitungan yang salah, tidak menulis satuan, dan menulis kesimpulan yang salah. Rata-rata soal dari masing-masing kelompok memiliki kriteria cukup dan baik.

Adapun soal uraian yang dikerjakan oleh siswa yang terdapat pada LKS, sebagai berikut: Sebuah prisma tegak memiliki volume 432 $\mathrm{cm}^{3}$. Alas prisma tersebut berbentuk segitiga siku-siku yang panjang sisi siku-sikunya $6 \mathrm{~cm}$ dan $8 \mathrm{~cm}$. Hitung tinggi prisma tersebut!

Berdasarkan soal uraian diatas diperoleh skor hasil pengerjaan oleh siswa, sebagai berikut:
Tabel 3. Skor Hasil Pengerjaan LKS siswa pada materi volume prisma untuk soal nomor 2

\begin{tabular}{|c|c|c|c|c|c|c|c|c|c|c|}
\hline \multirow{3}{*}{$\begin{array}{c}\text { Kelompok } \\
\text { Ke. }\end{array}$} & \multicolumn{5}{|c|}{ 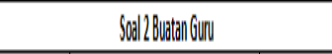 } & \multicolumn{5}{|c|}{ Soal Lbidan Siswa } \\
\hline & \multirow{2}{*}{ 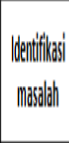 } & \multicolumn{3}{|c|}{ Stateley } & \multirow[b]{2}{*}{ Kesimplal } & \multirow{2}{*}{$\begin{array}{l}\text { |dentitithasi } \\
\text { mbsatat }\end{array}$} & \multicolumn{3}{|c|}{ Stratege } & \multirow[b]{2}{*}{ Kesimpulal } \\
\hline & & $\begin{array}{l}\text { Mewlis } \\
\text { Rumuls }\end{array}$ & Pentiturganal & Sotton & & & $\begin{array}{l}\text { Mendis } \\
\text { Punulus }\end{array}$ & Penthingegan & Sottlan & \\
\hline 1 & 2 & 1 & 1 & 0 & 2 & 2 & 1 & 1 & 1 & 2 \\
\hline 2 & 2 & 1 & 1 & 0 & 2 & 2 & 1 & 1 & 1 & 2 \\
\hline 3 & 2 & 1 & 1 & 0 & l & l & 1 & 1 & 1 & 2 \\
\hline 4 & 2 & 1 & 1 & 1 & 2 & 2 & 2 & 2 & 0 & 2 \\
\hline 5 & 2 & 1 & 1 & 1 & 1 & 2 & 2 & 2 & 0 & 1 \\
\hline 6 & 1 & 1 & 1 & 2 & 0 & 1 & 1 & 1 & 2 & 0 \\
\hline 1 & ? & 2 & ? & ? & ? & ? & 1 & 1 & 2 & ? \\
\hline 8 & 2 & 2 & 2 & 2 & 2 & 2 & 1 & 1 & 2 & 2 \\
\hline 9 & 2 & 2 & 2 & 2 & 2 & 2 & 0 & 2 & 2 & 2 \\
\hline 10 & 2 & 2 & 2 & 2 & 2 & 2 & 1 & 2 & 1 & 2 \\
\hline 11 & 2 & 0 & 1 & 1 & 1 & ? & 1 & l & 1 & 2 \\
\hline 12 & l & 1 & 1 & 1 & 1 & ? & ? & ? & 0 & 1 \\
\hline 13 & 2 & 2 & 1 & 1 & 1 & 2 & 1 & 1 & 0 & 1 \\
\hline 14 & 1 & 2 & 1 & 0 & 0 & 1 & 1 & 1 & 1 & 0 \\
\hline Ratoroto & 1.86 & 1.35 & 129 & 1,07 & 1,5 & 1.86 & 1,21 & $1,1,3$ & 1 & 1,5 \\
\hline Kriterila & Baik & bijk & Cukno & Culup & Bajk & Bajk & CWNDD & $B a k$ & Cowup & Bajk \\
\hline
\end{tabular}

Berdasarkan tabel 3 di atas terlihat bahwa pada soal buatan guru terdapat 4 kelompok yang tahap penyelesaian soal sudah sesuai dengan indikator tetapi pada soal buatan siswa keempat kelompok tersebut menulis rumus yang salah, perhitungan yang salah, dan menulis satuan yang salah.Ada bebrapa kelompok pada soal buatan guru menulis satuan yang salah akan tetapi pada soal buatan siswa memiliki kesimpulan yang benar. Disamping itu terdapat juga kelompok pada soal buatan guru memiliki perhitungan yang salah tetapi pada soal buatan siswa tidak menulis perhitungan. Selanjutnya, ada beberapa kelompok pada soal buatan guru dan soal buatan siswa tidak mengidentifikasi masalah dengan benar, menulis rumus yang salah, memiliki perhitungan yang salah, tidak menulis satuan, dan menulis kesimpulan yang salah. Rata-rata soal dari masing-masing kelompok memiliki kriteria cukup dan baik.

Adapun soal uraian yang dikerjakan oleh siswa yang terdapat pada LKS, sebagai berikut: Perhatikan gambar berikut! 


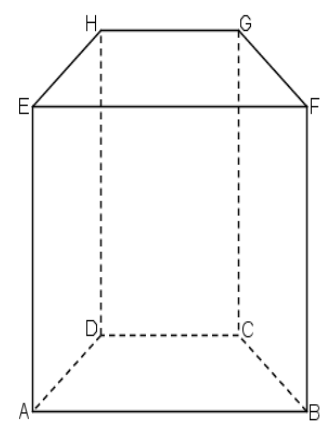

Alas prisma ABCD.EFGH di atas berbentuk trapesium sama kaki dengan panjang sisi-sisi sejajarnya adalah $12 \mathrm{~cm}$ dan $20 \mathrm{~cm}$, serta sisi miringnya $5 \mathrm{~cm}$. Jika tinggi prisma tersebut 25 $\mathrm{cm}$, maka hitunglah volume prisma!

Berdasarkan soal uraian diatas diperoleh skor hasil pengerjaan oleh siswa, sebagai berikut:

Tabel 4. Skor Hasil Pengerjaan LKS siswa pada materi volume prisma untuk soal nomor 3

\begin{tabular}{|c|c|c|c|c|c|c|c|c|c|c|}
\hline \multirow{3}{*}{$\begin{array}{l}\text { Kelampok } \\
\text { Ke. }\end{array}$} & \multicolumn{5}{|c|}{ Soal 3 Buatan Guru } & \multicolumn{5}{|c|}{ Sall 3Butata Sisva } \\
\hline & \multirow{2}{*}{$\begin{array}{c}\text { loentifilksí } \\
\text { mosilah }\end{array}$} & \multicolumn{3}{|c|}{ Strotegi } & \multirow[b]{2}{*}{ Kesimplan } & \multirow{2}{*}{$\begin{array}{l}\text { Bderititiksi } \\
\text { maselah }\end{array}$} & \multicolumn{3}{|c|}{ Strotegeg } & \multirow[b]{2}{*}{ Kesimpulan } \\
\hline & & $\begin{array}{l}\text { Menulis } \\
\text { Rumus }\end{array}$ & Pethitugan & Satuan & & & $\begin{array}{l}\text { Menulis } \\
\text { Rumus }\end{array}$ & Pethitugen & Sotuan & \\
\hline 1 & 2 & 2 & 2 & 0 & 2 & 2 & 2 & 2 & 2 & 2 \\
\hline 2 & 2 & 2 & 2 & 0 & 2 & 2 & 2 & 2 & 2 & 2 \\
\hline 3 & 2 & 2 & 1 & 0 & 2 & 2 & 2 & 2 & 2 & 2 \\
\hline 4 & 2 & 2 & 1 & 0 & 2 & 2 & 2 & 1 & 2 & 2 \\
\hline 5 & 2 & 1 & 1 & 1 & 1 & 2 & 1 & 1 & 2 & 1 \\
\hline 6 & 1 & 0 & 1 & 1 & 0 & 1 & 2 & 1 & 1 & 0 \\
\hline 7 & 2 & 0 & 1 & 1 & 2 & 2 & 1 & 1 & 1 & 2 \\
\hline 8 & 2 & 1 & 1 & 1 & 2 & 2 & 1 & 0 & 0 & 2 \\
\hline 9 & 2 & 1 & 1 & 1 & 2 & 2 & 1 & 2 & 2 & 2 \\
\hline 10 & 2 & 1 & 1 & 1 & 2 & 2 & 1 & 2 & 0 & 2 \\
\hline 11 & 2 & 1 & 2 & 2 & 2 & 2 & 1 & 2 & 1 & 2 \\
\hline 12 & 2 & 1 & 2 & 2 & 1 & 2 & 0 & 2 & 1 & 1 \\
\hline 13 & 2 & 0 & 0 & 0 & 1 & 2 & 2 & 2 & 1 & 1 \\
\hline 14 & 1 & 2 & 2 & 2 & 0 & 1 & 2 & 2 & 1 & 0 \\
\hline Roterofote & 1,86 & 1,14 & 1,29 & 0,86 & 1,5 & 1.86 & 1,43 & 1,57 & 1,29 & 1,5 \\
\hline Kiteria & Baik & Cukup & Cokkp & Cukvo & Baik & Baik & Baik & Baik & Cukup & Baik \\
\hline
\end{tabular}

Berdasarkan tabel 4 diatas terlihat bahwa pada soal buatan siswa terdapat 3 kelompok yang tahap penyelesaian soal sudah sesuai dengan indikator tetapi pada soal buatan guru ketiga kelompok tersebut menulis perhitungan yang salah, menulis satuan yang salah tetapi memiliki kesimpulan yang benar. Disamping itu ada 3 kelompok pada soal buatan guru tidak menulis satuan akan tetapi pada soal buatan siswa menulis satuan dengan benar. Ada 4 kelompok lagi pada soal buatan guru tidak menyimpulkan akan tetapi pada soal buatan siswa memberi kesimpulan dengan benar. Selanjutnya, ada 2 kelompok pada soal buatan guru dan soal buatan siswa tidak mengidentifikasi masalah dengan benar, menulis rumus yang salah, memiliki perhitungan yang salah, tidak menulis satuan, dan menulis kesimpulan yang salah. Rata-rata soal dari masing-masing kelompok memiliki kriteria cukup dan baik.

Adapun soal uraian yang dikerjakan oleh siswa yang terdapat pada LKS, sebagai berikut: Sebuah limas memiliki alas berbentuk persegi panjang dengan ukuran $25 \mathrm{~cm} \times 15 \mathrm{~cm}$. Jika tinggi limas $7 \mathrm{~cm}$, maka hitunglah volume limas tersebut!

Berdasarkan soal uraian diatas diperoleh skor hasil pengerjaan oleh siswa, sebagai berikut:

Tabel 5. Skor Hasil Pengerjaan LKS siswa pada materi volume limas untuk soal nomor 1

\begin{tabular}{|c|c|c|c|c|c|c|c|c|c|c|}
\hline \multirow{3}{*}{$\begin{array}{c}\text { Kelompok } \\
\text { Ke. }\end{array}$} & \multicolumn{5}{|c|}{ Sool 1 Buatan Guru } & \multicolumn{5}{|c|}{ Soal 1 Buatan Siswa } \\
\hline & \multirow[b]{2}{*}{\begin{tabular}{|l} 
Identifiksil \\
mosslat
\end{tabular}} & \multicolumn{3}{|c|}{ Strategi } & \multirow[b]{2}{*}{ Kesimpulan } & \multirow{2}{*}{$\begin{array}{l}\text { Identitiksasi } \\
\text { massalah }\end{array}$} & \multicolumn{3}{|c|}{ Strategi } & \multirow[b]{2}{*}{ Kesimpulan } \\
\hline & & $\begin{array}{l}\text { Mendis } \\
\text { Runus } \\
\end{array}$ & Pentitungan & Sattuan & & & $\begin{array}{l}\text { Menul's } \\
\text { Rumus }\end{array}$ & Penhitungan & Sottuan & \\
\hline 1 & 2 & 2 & 2 & 2 & 2 & 2 & 2 & 2 & 0 & 2 \\
\hline 2 & 2 & 2 & 2 & 2 & 2 & 2 & 2 & 2 & 0 & 2 \\
\hline 3 & 2 & 2 & 2 & 2 & 2 & 2 & 2 & 2 & 0 & 2 \\
\hline 4 & 2 & 2 & 2 & 2 & 2 & 2 & 2 & 2 & 2 & 2 \\
\hline 5 & 2 & 2 & 2 & 2 & 1 & 2 & 2 & 1 & 2 & 1 \\
\hline 6 & 1 & 1 & 1 & 0 & 0 & 1 & 0 & 1 & 2 & 0 \\
\hline 7 & 2 & 2 & 1 & 0 & 2 & 2 & 0 & 1 & 2 & 2 \\
\hline 8 & 2 & 2 & 1 & 0 & 2 & 2 & 1 & 1 & 2 & 2 \\
\hline 9 & 2 & 2 & 1 & 0 & 2 & 2 & 1 & 1 & 2 & 2 \\
\hline 10 & 2 & 2 & 1 & 1 & 2 & 2 & 1 & 2 & 1 & 2 \\
\hline 11 & 2 & 2 & 1 & 1 & 2 & 2 & 2 & 2 & 1 & 2 \\
\hline 12 & 2 & 2 & 2 & 1 & 1 & 2 & 2 & 2 & 1 & 1 \\
\hline 13 & 2 & 2 & 2 & 2 & 1 & 2 & 2 & 2 & 1 & 1 \\
\hline 14 & 1 & 2 & 1 & 2 & 0 & 1 & 2 & 2 & 1 & 0 \\
\hline Retar-otto & 1.86 & 1,93 & 1,5 & 1,21 & 1,5 & 1,86 & 1,5 & 1,64 & 1,21 & 1,5 \\
\hline Kriteria & Bajk & Baik & Baik & Cukup & Baik & Baik & Baik & Baik & Cukup & Baik \\
\hline
\end{tabular}

Berdasarkan tabel 5 di atas terlihat bahwa pada soal buatan guru terdapat 4 kelompok yang tahap penyelesaian soal sudah sesuai dengan indikator tetapi pada soal buatan siswa ketiga kelompok tersebut ada yang yang tidak menulis satuan. Ada beberapa kelompok pada soal buatan guru menulis perhitungan yang salah akan tetapi pada soal buatan siswa menulis perhitungan yang benar. Namun ada juga beberapa kelompok pada soal buatan guru menulis satuan yang salah akan tetapi pada soal buatan siswa menulis satuan yang benar. Selanjutnya, ada beberapa kelompok pada soal buatan guru dan soal buatan siswa tidak mengidentifikasi masalah dengan benar, 
menulis rumus yang salah, memiliki perhitungan yang salah, tidak menulis satuan, dan menulis kesimpulan yang salah. Rata-rata soal dari masing-masing kelompok memiliki kriteria cukup dan baik.

Adapun soal uraian yang dikerjakan oleh siswa yang terdapat pada LKS, sebagai berikut: Perhatikan gambar berikut!

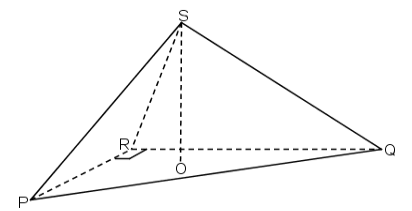

Alas limas pada gambar diatas berbentuk segitiga siku-siku di R dengan volume $60 \mathrm{~cm}^{3}$ dan tinggi $6 \mathrm{~cm}$. Jika panjang PR adalah $5 \mathrm{~cm}$. Tentukan:

a. luas alas limas S.PQR

b. panjang QR

Berdasarkan soal uraian diatas diperoleh skor hasil pengerjaan oleh siswa, sebagai berikut:

Tabel 6.Skor Hasil Pengerjaan LKS siswa pada materi volume limas untuk soal nomor 2

\begin{tabular}{|c|c|c|c|c|c|c|c|c|c|c|}
\hline \multirow{3}{*}{$\begin{array}{l}\text { Kelompok } \\
\text { Ke. }\end{array}$} & \multicolumn{5}{|c|}{ Soal 2 Buatan Guru } & \multicolumn{5}{|c|}{ Soal 2 Buatan Siswa } \\
\hline & \multirow{2}{*}{$\begin{array}{l}\text { Identifikasi } \\
\text { massalah }\end{array}$} & \multicolumn{3}{|c|}{ Strateggi } & \multirow[b]{2}{*}{ Kesimpulan } & \multirow{2}{*}{$\begin{array}{c}\text { Identifikiksi } \\
\text { massalah }\end{array}$} & \multicolumn{3}{|c|}{ Strategi } & \multirow[b]{2}{*}{ Kesimpulan } \\
\hline & & $\begin{array}{l}\text { Menulis } \\
\text { Rumus }\end{array}$ & Perhitungan & Satuan & & & $\begin{array}{l}\text { Menulis } \\
\text { Rumus }\end{array}$ & Perhitungan & Satuan & \\
\hline 1 & 2 & 1 & 2 & 2 & 2 & 2 & 2 & 2 & 2 & 2 \\
\hline 2 & 2 & 1 & 2 & 2 & 2 & 2 & 2 & 2 & 2 & 2 \\
\hline 3 & 2 & 1 & 2 & 2 & 2 & 2 & 2 & 2 & 2 & 2 \\
\hline 4 & 2 & 1 & 2 & 1 & 2 & 2 & 2 & 2 & 2 & 2 \\
\hline 5 & 2 & 2 & 1 & 1 & 1 & 2 & 1 & 1 & 2 & 1 \\
\hline 6 & 1 & 2 & 1 & 1 & 0 & 1 & 1 & 1 & 2 & 0 \\
\hline 7 & 2 & 2 & 2 & 2 & 2 & 2 & 1 & 2 & 1 & 2 \\
\hline 8 & 2 & 2 & 2 & 2 & 2 & 2 & 1 & 2 & 1 & 2 \\
\hline 9 & 2 & 2 & 2 & 2 & 2 & 2 & 2 & 2 & 2 & 2 \\
\hline 10 & 2 & 1 & 0 & 0 & 2 & 2 & 0 & 2 & 2 & 2 \\
\hline 11 & 2 & 1 & 0 & 0 & 2 & 2 & 0 & 0 & 0 & 2 \\
\hline 12 & 2 & 0 & 2 & 1 & 1 & 2 & 2 & 0 & 0 & 1 \\
\hline 13 & 2 & 0 & 2 & 1 & 1 & 2 & 2 & 0 & 0 & 1 \\
\hline 14 & 1 & 2 & 2 & 1 & 0 & 1 & 2 & 0 & 0 & 0 \\
\hline Ratorota & 1,86 & 1,29 & 1,57 & 1,29 & 1,5 & 1,86 & 1,43 & 1,29 & \begin{tabular}{|l|}
1,29 \\
\end{tabular} & 1,5 \\
\hline Kriteria & Baik & Cukup & Baik & Cukup & Baik & Baik & Baik & Cukup & Cukup & Baik \\
\hline
\end{tabular}

Berdasarkan tabel 6 di atas terlihat bahwa pada soal buatan siswa terdapat 4 kelompok yang tahap penyelesaian soal sudah sesuai dengan indikator tetapi pada soal buatan guru keempat kelompok tersebut tidak menulis rumus dan satuan dengan. Ada beberapa kelompok pada soal buatan guru menulis rumus yang salah akan tetapi pada soal buatan siswa menulis rumus yang benar. Terdapat juga beberapa kelompok pada soal buatan guru menulis rumus yang benar akan tetapi pada soal buatan siswa menulis rumus yang salah. Disamping itu, ada juga beberapa kelompok pada soal buatan guru menulis satuan yang benar akan tetapi pada soal buatan siswa menulis satuan yang salah. Selanjutnya, ada beberapa kelompok pada soal buatan guru dan soal buatan siswa tidak mengidentifikasi masalah dengan benar, menulis rumus yang salah, memiliki perhitungan yang salah, tidak menulis satuan, dan menulis kesimpulan yang salah. Rata-rata soal dari masing-masing kelompok memiliki kriteria cukup dan baik.

Adapun soal uraian yang dikerjakan oleh siswa yang terdapat pada LKS, sebagai berikut: Perhatikan gambar berikut!

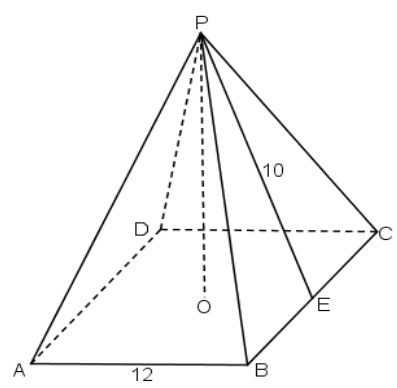

Alas sebuah limas beraturan pada gambar diatas berbentuk persegi dengan panjang sisi 12 $\mathrm{cm}$. Jika tinggi segitiga pada bidang tegaknya adalah $10 \mathrm{~cm}$, hitunglah:

a. Tinggi limas

b. Volume limas tersebut

Berdasarkan soal uraian diatas diperoleh skor hasil pengerjaan oleh siswa, sebagai berikut:

Tabel 7. Skor Hasil Pengerjaan LKS siswa pada materi volume limas untuk soal nomor 3

\begin{tabular}{|c|c|c|c|c|c|c|c|c|c|c|}
\hline \multirow{3}{*}{$\begin{array}{c}\text { Kelompok } \\
\text { Ke. }\end{array}$} & \multicolumn{5}{|c|}{ Soal 3 Buatan Guru } & \multicolumn{5}{|c|}{ Soal 3 Buatan Siswa } \\
\hline & \multirow{2}{*}{$\begin{array}{c}\text { Identifikiksi } \\
\text { massalah }\end{array}$} & \multicolumn{3}{|c|}{ Strategi } & \multirow[b]{2}{*}{ Kesimpulan } & \multirow{2}{*}{$\begin{array}{l}\text { Identifiksas } \\
\text { massalah }\end{array}$} & \multicolumn{3}{|c|}{ Strategi } & \multirow[b]{2}{*}{ Kesimpula } \\
\hline & & \begin{tabular}{|l} 
Menulis \\
Runus \\
\end{tabular} & Perhitungan & Satuan & & & \begin{tabular}{|l} 
Menulis \\
Rumus \\
\end{tabular} & Perhitungan & Satuan & \\
\hline 1 & 2 & 2 & 2 & 1 & 2 & 2 & 2 & 2 & 2 & 2 \\
\hline 2 & 2 & 2 & 2 & 1 & 2 & 2 & 2 & 2 & 2 & 2 \\
\hline 3 & 2 & 2 & 2 & 1 & 2 & 2 & 2 & 2 & 2 & 2 \\
\hline 4 & 2 & 2 & 2 & 1 & 2 & 2 & 2 & 2 & 2 & 2 \\
\hline 5 & 2 & 2 & 1 & 1 & 1 & 2 & 2 & 1 & 2 & 1 \\
\hline 6 & 1 & 2 & 2 & 1 & 0 & 1 & 2 & 2 & 1 & 0 \\
\hline 7 & 2 & 2 & 1 & 2 & 2 & 2 & 2 & 1 & 1 & 2 \\
\hline 8 & 2 & 2 & 2 & 2 & 2 & 2 & 2 & 2 & 1 & 2 \\
\hline 9 & 2 & 1 & 2 & 2 & 2 & 2 & 1 & 2 & 0 & 2 \\
\hline 10 & 2 & 1 & 1 & 0 & 2 & 2 & 1 & 1 & 2 & 2 \\
\hline 11 & 2 & 1 & 1 & 0 & 2 & 2 & 1 & 1 & 2 & 2 \\
\hline 12 & 2 & 1 & 2 & 2 & 1 & 2 & 1 & 2 & 1 & 1 \\
\hline 13 & 2 & 1 & 2 & 2 & 1 & 2 & 1 & 2 & 1 & 1 \\
\hline 14 & 1 & 1 & 2 & 2 & 0 & 1 & 1 & 2 & 1 & 0 \\
\hline Ratarofta & 1,86 & 1,57 & 1,71 & 1,29 & 1,5 & 1,86 & 1,57 & 1,71 & 1,43 & 1,5 \\
\hline Kriteria & Baik & Baik & Baik & Cukup & Baik & Baik & Boik & Baik & Baik & Baik \\
\hline
\end{tabular}


Berdasarkan tabel 7 di atas terlihat bahwa pada soal buatan siswa terdapat 4 kelompok yang tahap penyelesaian soal sudah sesuai dengan indikator tetapi pada soal buatan guru keempat kelompok tersebut tidak menulis satuan dengan benar. Selanjutnya, ada beberapa kelompok pada soal buatan guru dan soal buatan siswa tidak mengidentifikasi masalah dengan benar, menulis rumus yang salah, memiliki perhitungan yang salah, tidak menulis satuan, dan menulis kesimpulan yang salah. Rata-rata soal dari masing-masing kelompok memiliki kriteria cukup dan baik.

Berdasarkan tabel 2, tabel 3, tabel 4, tabel 5, tabel 6, tabel 7 di atas terlihat bahwa masingmasing soal dan penyelesaian yang siswa buat memiliki kriteria cukup dan baik. Ada beberapa kelompok dalam menyelesaikan soal yang guru berikan maupun soal yang siswa buat sendiri pada tahap penyelesian soal sudah sesuai dengan indikator pencapaian soal seperti menulis lengkap dan benar apa saja yang diketahui dan ditanya pada soal, menulis rumus yang benar, memiliki perhitungan yang benar, menulis satuan yang benar serta membuat kesimpulan yang benar. Disamping itu ada juga beberapa kelompok yang tidak menulis apa saja yang diketahui pada soal, menulis rumus yang salah, menulis perhitungan yang salah, tidak menuliskan satuan dan kesimpulan.Adapun salah satu soal dan penyelesaian yang dibuat oleh siswa sebagai berikut:

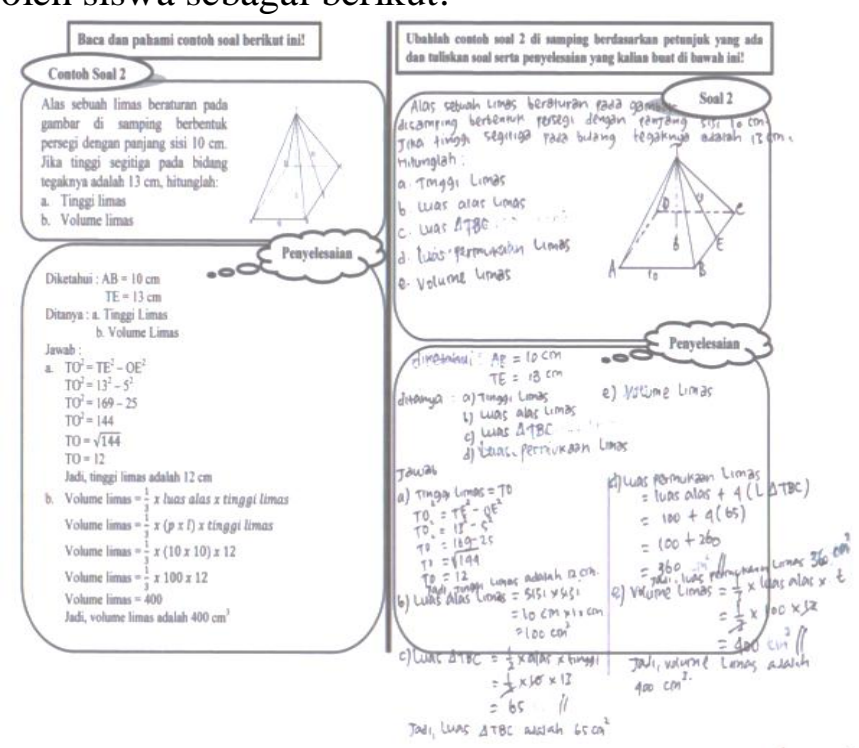

Gambar 1. Contoh soal dan penyelesaian yang dibuat oleh kelompok 10 pada pertemuan ke-4
Berdasarkan gambar 1 diatas terlihat bahwa siswa dalam membuat soal serta tahap dalam penyelesaian soal sudah sesuai dengan indikator penyelesaian soal seperti menuliskan apa saja yang diketahui dan ditanya pada soal, menuliskan rumus yang benar, menuliskan perhitungan yang benar dan membuat satuan yang benar serta membuat kesimpulan dari penyelesaian yang siswa buat.

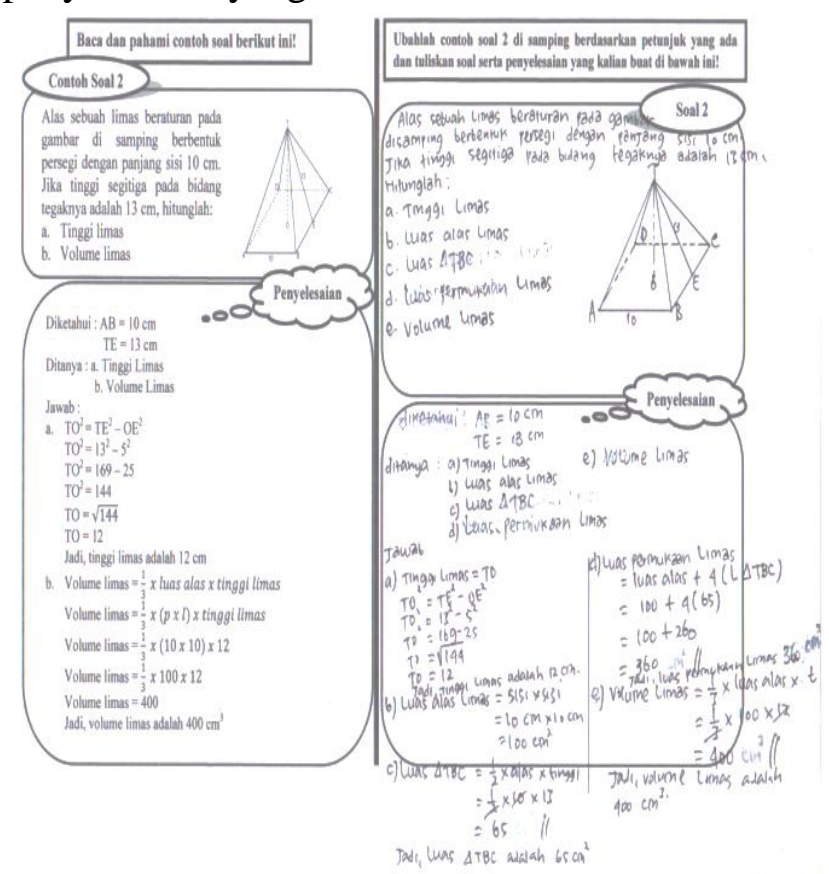

Gambar 2. Contoh soal dan penyelesaian yang dibuat oleh kelompok 10 pada pertemuan ke-5

Berdasarkan gambar 2 diatas terlihat bahwa siswa dalam membuat soal serta tahap dalam penyelesaian soal sudah sesuai dengan indikator penyelesaian soal seperti menuliskan apa saja yang diketahui dan ditanya pada soal, menuliskan rumus yang benar, menuliskan perhitungan yang benar dan membuat satuan yang benar serta membuat kesimpulan dari penyelesaian yang siswa buat.

\section{KESIMPULAN DAN SARAN}

\section{A. Kesimpulan}

Dapat disimpulkan bahwa kemampuan siswa dalam menjawab soal uraian berdasarkan soal yang dibuat oleh guru maupun soal dan penyelesaian yang dibuat oleh siswa tidak terdapat perbedaan dalam langkah-langkah penyelesaiannya. Disamping itu, dalam 
pengerjaan soal sudah sesuai dengan indikator.Namun ada beberapa siswa dalam langkah-langkah penyelesaian soal tidak sesuai dengan indikator, seperti:

1. Tidak menulis rumus

2. Tidak menulis perhitungan

3. Tidak menulis satuan

4. Tidak menulis kesimpulan

B. Saran

Adapun saran dalam artikel ini, sebagai berikut:

1. Dalam membuat soal uraian dan penyelesaiannya perlu diperhatikan langkah-langkah penyelesaiannya

2. Pada pembelajaran Problem Posing tipe Post Solution perlu diperjelas langkahlangkah dalam pembelajaran tersebut

3. Siswa dalam membuat soal baru dengan bervariasi sesuai dengan pembelajaran Problem Posing tipe Post Solution dengan tahap penyelesaian soal sesuai dengan indikator.

\section{DAFTAR PUSTAKA}

Ngalimun. (2012). Strategi dan Model Pembelajaran. Yogyakarta: Aswaja Pressindo.

Soedjadi, R. 2000. Kiat Pendidikan Matematika di Indonesia. Direktorat Jenderal Pendidikan Tinggi Departemen Pendidikan Nasional.

Sugiyono. 2011. Metode Penelitian Pendidikan Pendekatan Kuantitatif, Kualitatif, dan $R \& D$. Bandung: Alfabeta.

Sudiyono, Anas. 2008. Pengantar Evaluasi Pendidikan. Jakarta: PT Raja Grafindo Persada. 